\title{
Pestivirus Infection Does Not Affect Prevalence of Brucella melitensis and Encephalitozoon cuniculi in Small Ruminants of the State of Nuevo Leon, Mexico
}

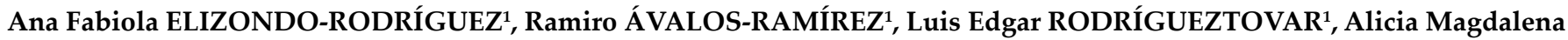 \\ NEVÁREZ-GARZA ${ }^{1}$, Ricardo GOMEZ-FLORES ${ }^{2}$ and Castillo-Velázquez $\mathbf{U}^{1 *}$ \\ ${ }^{1}$ Department of Veterinary Immunology, School of Veterinary Medicine and Zootechnics, Autonomous University of Nuevo León, México \\ ${ }^{2}$ Autonomous University of Nuevo León, Faculty of Biological Sciences, Department of Microbiology, Laboratory of Immunology and Virology, San \\ Nicolás de los Garza, N.L., Mexico
}

*Corresponding author: U Castillo-Velázquez, Department of Veterinary Immunology, School of Veterinary Medicine and Zootechnics, Autonomous University of Nuevo León, México; E-mail: uziel_c@hotmail.com

Received: February 03, 2021; Accepted: February 08, 2021; Published: February 11, 2021

\begin{abstract}
Background: Members of the Pestivirus genus cause diseases associated with immunosuppression in cattle, which are involved in important economic losses. Similarly, Brucella melitensis is an intracellular bacterium of goats and sheep, whose infection significantly impacts on livestock production, whereas, Encephalitozoon cuniculi is an intracellular parasite of small ruminants, causing a subclinical disease, which worsens if they are immunosuppressed. In the present study, susceptibility to B. melitensis and E. cuniculi in small ruminants infected with Pestivirus was investigated.
\end{abstract}

Methods: Two hundred goat serological samples were obtained in production units proportionally distributed in 4 rural development districts (RDD) in the state of Nuevo León, Mexico. For the serological identification of Pestivirus, B. melitensis, and E. cuniculi, ELISA, Rose Bengal test, and carbon immunoassay methods were respectively used.

Results: Twenty five animals selected from each RDD were positive for Pestivirus. In addition, B. melitensis and E. cuniculi seroprevalence was $96 \%$ and $97.5 \%$, respectively, regardless of Pestivirus infection.

Conclusion: Pestivirus does not influence animals susceptibility to B. melitensis and E. cuniculi infection. In addition, B. melitensis and E. cuniculi prevalence in the state of Nuevo Leon, Mexico was demonstrated.

Keywords: Small ruminants, Seroprevalence, Antibodies, Pestivirus, Brucella melitensis, Bovine viral diarrhea, Encephalitozoon cuniculi, Microsporidia

\section{Introduction}

Members of the Pestivirus genus of the Flaviviridae family are the causative agents of bovine viral diarrhea, border disease, and classic swine fever [1]. These are some of the most common ailments associated with immunosuppression of cattle, which increases secondary and opportunistic infections [2]. Infected animals show marked temporary immunosuppression resulting from leukocytes viral infection [3]. In these cells, viruses replicate, leading to genetic changes that eventually cause their adaptation and interspecies interaction. Pestivirus infections persist and disseminate within domestic and wild artiodactyls, causing significant economic losses [4].

These viruses cross placenta during pregnancy, inducing embryo death and abortions, reproductive disorders such as fetal mummification, stillbirths, congenital disabilities, and malformations [5]. By colonizing the fetus during early gestational development, viruses cause persistent infection, characterized by immunological tolerance [6]. However, the disease is often subclinical and is only revealed by the presence of specific antibodies [7]. However, if the infection occurs in the first third of pregnancy before the immune system develops, the fetus will become persistently infected and produce a high viral load without developing an immune response [8]. Such animals (infected with non-cytopathic viruses) are weak and more prone to infections of the digestive and respiratory tract. If these animals are infected with another cytopathic type-strain, they develop a disease called mucosal disease with $100 \%$ mortality [9].

Pestiviruses have a worldwide distribution, whose prevalence varies among countries and regions, becoming an essential factor in virus transmission between animal species. In Mexico, there is a $33.6 \%$ prevalence of Pestivirus in cattle [10], whereas globally its prevalence ranges from $2 \%$ to $25 \%$ [11]. However, studies on goats or sheep in Mexico have not been developed to date. Some control programs against Pestiviruses are based on the application of biosecurity measures in livestock, which involve early evaluation of the herd searching for signs of infection, implementation of a vaccination 
system where the disease is present, determination and elimination of persistently infected animals [12], and periodic monitoring of the herds [8]. Control and eradication models depend on the prevalence and control laws of each country and region.

In addition, Encephalitozoon cuniculi is an opportunistic and obligated intracellular parasite, known to be a pathogen to different species, including small ruminants [13]. Generally, the infection is subclinical, however, in immunosuppressed animals, it is common to find nephritis, non-suppurative encephalitis, and vasculitis, among other affections [14]. The transmission of this intracellular agent is by ingestion or inhalation of the spores in urine or feces.

On the other hand, Brucella melitensis is a Gram-negative intracellular bacterium, endemic of sheep and goats, which is highly contagious to humans. Brucella affects the mammary gland, uterus, and testicles, causing abortions in pregnant females, and orchitis in males [15]. This disease causes an economic impact on livestock production, especially in the countries in which ovine and caprine production is essential [16].

In the present study, prevalence of B. melitensis and E. cuniculi in goats and sheep of Northeast Mexico, infected with Pestivirus was investigated.

\section{Methods}

\section{Study Area and Animals Source}

This study was developed with serum samples from 200 small ruminants (goats) proportionally distributed in the rural development districts (RDD) Anahuac, Apodaca, Montemorelos, and Galeana of the state of Nuevo Leon, Mexico. Animal serum samples were evaluated for the presence of B. melitensis and E. cuniculi antibodies by the Rose Bengal test and the carbon immunoassay (CIA) method respectively.

\section{Detection of Antibodies against Pestivirus}

A competitive ELISA (INgezim BVD Compac, Ingenasa, Madrid, Spain) was used to detect Pestivirus specific antibodies against NS23 antigen (p80/p125 inactivated viral antigens) in goats and sheep. Sensitivity and specificity of the test are $95 \%$ and $92.0 \%$, respectively, according to the manufacturer.

\section{Detection of Antibodies to B. melitensis}

The hemagglutination Rose Bengal test was used to detect $B$. melitensis antibodies in serum [17]. Antigen stained with Rose Bengal was used and buffered at a low $\mathrm{pH} ; 25 \mu \mathrm{l}$ of serum samples were placed in a plate, along with $25 \mu \mathrm{l}$ of antigen. Mixture was then stirred for approximately 4 minutes until hemagglutination was observed; if there was no evidence of agglutination, it was considered as unfavorable.

\section{Detection of antibodies to $E$. cuniculi}

CIA method was performed according to manufacturer's instructions (Medicago, Uppsala, Sweden). It consists of using $E$. cuniculi complete spores (killed by heat) suspended with carbon contained in the kit, and exposing them to serum samples; presence of antibodies will be visualized as agglutination under optical microscopy at 40X [18].
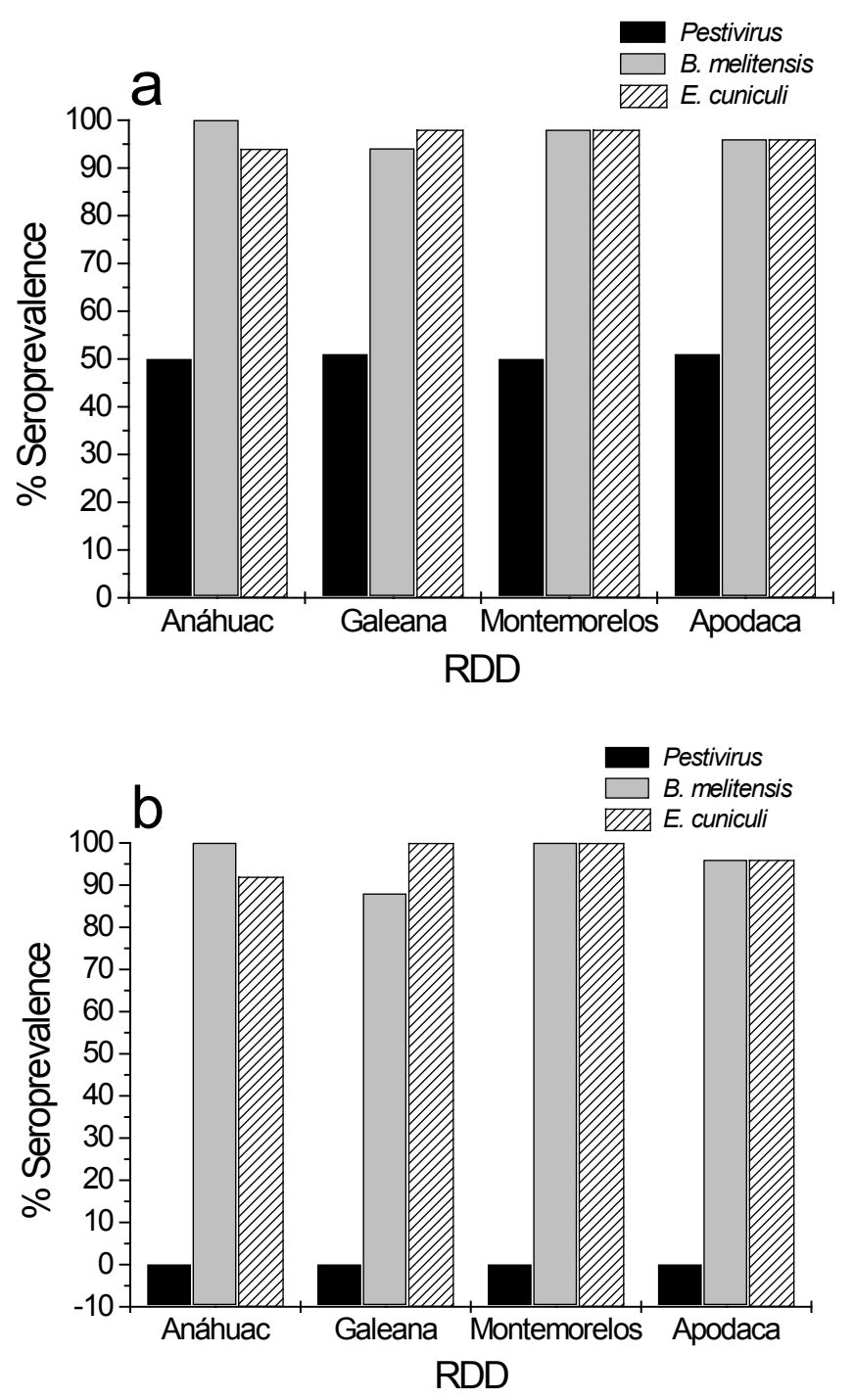

Figure 1: Seroprevalence of Pestivirus, B. melitensis, and E. cuniculi in RDD goats positive (a) and negative (b) for Pestivirus infection.

\section{Results}

As shown in Figure 1a, $50.5 \% \pm 0.6 \%$ of animals from RDDs were positive for Pestivirus, whereas seroprevalence for B. melitensis and $E$. cuniculi was $97 \% \pm 2.5 \%$ and $96.5 \% \pm 1.9 \%$, respectively. In Pestivirusfree animals, B. melitensis and E. cuniculi seroprevalence was $96 \% \pm$ $5.65 \%$ and $97 \% \pm 3.8 \%$ respectively (Figure $1 b$ ).

\section{Discussion}

Pestivirus infection causes immunosuppression, affecting IFN- $\gamma$ and IL-2 production, phagocytosis and elimination of microorganisms, lymphocytes, and MHC regulation, which may reactivate some microorganisms already present or allow other opportunists to impair the infection $[8,9,20]$.

The aim of the present study was to evaluate the role of Pestivirus infection on B. melitensis and E. cuniculi prevalence, potentially impairing the development of disease in small ruminants. We expected that those individuals infected with Pestivirus would be more 
susceptible to infection by Brucella and Encephalitozoon. However, there was no difference on the prevalence of these microorganisms in control animals not infected with Pestivirus. This can be explained by not considering additional environmental or management factors such as malnutrition and hygiene conditions in pens.

B. melitensis and E. cuniculi co-infection was present in goats of the state of Nuevo Leon, Mexico, with a combined seroprevalence of animals infected and not infected with Pestivirus of about 97\%, which is very high, compared with that of other states such as Veracruz (18.18\% seroprevalence) [21], and with results from other countries, including Nigeria (9.6\% seroprevalence) [22] and Colombia (1.2\% seroprevalence) [23]. The high prevalence of E. cuniculi should be taken into consideration, since this disease is not endemic of Nuevo Leon or even Mexico. There are no studies reporting seroprevalence or cases of this microorganism in small ruminants. However, presence of microsporidia in ruminants has been reported [24]; Juránková et al. [24] showed no significant difference between Enterocytozoon bieneusi prevalence of $17.5 \%$ and $13.33 \%$ in bovine herds positive and negative for Pestivirus respectively. Despite there are no reports to date about co-infections with E. cuniculi, these data indicated the potential of microsporidia to use ruminants as hosts [25].

The first report of specific antibodies against E. cuniculi in ruminants showed that were $43.6 \%$ seropositivity of Slovakia cows [26], in which immunohistochemical tests showed the presence of spores, suggestive of E. cuniculi in the placenta, brain, liver, myocardium, kidneys, and lungs of aborted fetuses. These findings are compatible with those observed in fetuses aborted by microorganisms of the Brucella genus, although they corresponded to E. cuniculi. This is one of the main reasons why the family Brucella was considered within the organisms to study in this investigation $[26,27]$.

Pestivirus infection can maintain an immunosuppression status in animals because of the decrease in CD $4+$ and CD $8+$ lymphocytes in peripheral blood, as observed in HIV infections [20]. Other reports of Pestivirus-induced immunosuppression, resulted in the presence of opportunistic pathogens such as Neospora caninum, Mycoplasma bovis, and Salmonella typhimurium in ruminants [28,29].

\section{Conclusion}

We have demonstrated that Pestivirus infection is not a predisposing factor to acquire other opportunist intracellular microorganisms, since $B$. melitensis and E. cuniculi were prevalent in small ruminants in the absence of the virus. In addition, a significant prevalence of $97 \%$ for B. melitensis was observed, whereas E. cuniculi seroprevalence was $96.5 \%$ in goats of the state of Nuevo Leon, Mexico, that were infected with Pestivirus. Similarly, in Pestivirus-free animals, prevalence of B. melitensis and E. cuniculi was $96 \%$ and $97 \%$ respectively. Furthermore, we believe this is the first report on E. cuniculi seroprevalence in small ruminants in Mexico.

\section{References}

1. Isken O, Langerwisch U, Schonherr R, Lamp B, Schroder K, et al. (2014) Functional characterization of bovine viral diarrhea virus nonstructural protein $5 \mathrm{a}$ by reverse genetic analysis and live cell imaging. J Virol 88: 82-98. [crossref]

2. Otachel-Hawranek J (2004) Reproductive losses in dairy cattle infected with BVDMD virus - A field study. Bull Vet Inst Pulawy 48: 355-359.
3. Brewoo JN, Haase CJ, Sharp P, Schultz RD (2007) Leukocyte profile of cattle persistently infected with bovine viral diarrhea virus. Vet Immunol Immunopathol 115: 369-374. [crossref]

4. Tao J, Liao J, Wang Y, Zhang X, Wang J, Zhu G (2013) Bovine viral diarrhea virus (BVDV) infections in pigs. Vet Microbiol 165: 185-189. [crossref]

5. Ross CE, Dubovi EJ, Donis RO (1986) Herd problem of abortions and malformed calves attributed to bovine viral diarrhea. J Am Vet Med Assoc 188: 618-619. [crossref]

6. Peterhans E, Jungi TW, Schweizer M (2003) BVDV and innate immunity. Biologicals 31: 107-112. [crossref]

7. Letellier C, Kerkhofs P, Wellemans G, Vanopdenbosch E (1999) Detection and genotyping of bovine diarrhea virus by reverse transcription-polymerase chain amplification of the 5' untranslated region. Vet Microbiol 64: 155-167. [crossref]

8. Lanyon SR, Hill FI, Reichel MP, Brownlie J (2014) Bovine viral diarrhoea: Pathogenesis and diagnosis. Vet J 199: 201-209. [crossref]

9. Rajput MK, Darweesh MF, Park K, Braun LJ, Mwangi W, et al. (2014) The effect of bovine viral diarrhea virus (BVDV) strains on bovine monocyte-derived dendritic cells (Mo-DC) phenotype and capacity to produce BVDV. Virol J 11: 1-15. [crossref]

10. Sánchez-Castilleja YM, Rodríguez Diego JG, Pedroso M, Cuello S (2012) Simultaneidad serológica de Neospora caninum con Brucella abortus y los virus de la rinotraqueítis infecciosa bovina y diarrea viral bovina en bovinos pertenecientes al Estado de Hidalgo, México. Rev Salud Anim 34: 95-100.

11. Bachofen C, Bollinger B, Peterhans E, Stalder H, Schweizer M (2013) Diagnostic gap in Bovine viral diarrhea virus serology during the periparturient period in cattle. $J$ Vet Diagn Invest 25: 655-661. [crossref]

12. Dias NL, Fonseca Júnior AA, Oliveira AM, Sales ÉB, Alves BRC, et al. (2014) Validation of a real time PCR for classical swine fever diagnosis. Vet Med Int 2014: 171235-171239. [crossref]

13. Morsy EA, Salem HM, Khattab MS, Hamza DA, Abuowarda MM (2020) Encephalitozoon cuniculi infection in farmed rabbits in Egypt. Acta Vet Scand 62: $1-11$.

14. Webster JD, Miller MA, Vemulapalli R (2008) Encephalitozoon cuniculi-associated placentitis and perinatal death in an alpaca (Lama pacos). Vet Pathol 45: 255-258. [crossref]

15. Ganter M (2015) Zoonotic risks from small ruminants. Vet Microbiol 181: 53-65. [crossref]

16. Juste RA, Leginagoikoa I, Villoria M, Minguijon E, Elguezabal N, et al. (2013) Control of brucellosis and of respiratory Small Ruminant Lentivirus infection in small ruminants in the Basque country, Spain. Small Rumin Res 110:115-119.

17. Ismael AB, Swelum AAA, Mostafa SAH, Alhumiany ARA (2016) Latex agglutination using the periplasmic proteins antigen of Brucella melitensis is a successful, rapid, and specific serodiagnostic test for ovine brucellosis. Int J Immunopathol Pharmacol 29: 480-487. [crossref]

18. Boot R, Hansen AK, Hansen CK, Nozari N, Thuis HC (2000) Comparison of assays for antibodies to Encephalitozoon cuniculi in rabbits. Lab Anim 34: 281-289. [crossref]

19. Ridpath J (2010) The contribution of infections with bovine viral diarrhea viruses to bovine respiratory disease. Vet Clin Food Anim Pract 26: 335-348. [crossref]

20. Chase CC, Thakur N, Darweesh MF, Morarie-Kane SE, Rajput MK (2015) Immune response to bovine viral diarrhea virus-looking at newly defined targets. Anim Health Res Rev 16: 4-14. [crossref]

21. Román-Ramírez DL, Martínez-Herrera DI, Villagómez-Cortés JA, Peniche-Cardeña AEDeJ, Morales-Álvarez F, et al. (2017) Epidemiología de la brucelosis caprina en la Zona Centro del Estado de Veracruz. Gac Med Mex 153: 26-30.

22. Olufemi OT, Dantala DB, Shinggu PA, Dike UA, Otolorin GR, et al. (2018) Seroprevalence of brucellosis and associated risk factors among indigenous breeds of goats in Wukari, Taraba State, Nigeria. J Pathog 2018: 1-5. [crossref]

23. Tique V, Daza E, Álvarez J, Mattar S (2010) Seroprevalence of Brucella abortus and ocurrence of Brucella melitensis in goats and sheep of Cesar and Sucre. Rev UDCA actual divulg cient 13: 133-139.

24. Juránková J, Kamler M, Kovařč́k K, Koudela B (2013) Enterocytozoon bieneusi in bovine viral diarrhea virus (BVDV) infected and noninfected cattle herds. Res Vet Sci 94:100-104. [crossref] 
Castillo-Velázquez U (2021) Pestivirus Infection Does Not Affect Prevalence of Brucella melitensis and Encephalitozoon cuniculi in Small Ruminants of the State of Nuevo Leon, Mexico

25. Kašičková D, Sak B, Kváč M, Ditrich O (2007) Detection of Encephalitozoon cuniculi in a new host - Cockateel (Nymphicus hollandicus) using molecular methods. Parasitol Res 101: 1685-1688. [crossref]

26. Halánová M, Letková V, MacÁk V, Štefkovič M, Halán M (1999) The first finding of antibodies to Encephalitozoon cuniculi in cows in Slovakia. Vet Parasitol 82: 167-171. [crossref]

27. Ocholi RA, Kwaga JKP, Ajogi I, Bale JOO (2005) Abortion due to Brucella abortus in sheep in Nigeria. Rev Sci Tech.; 24: 973-979. [crossref]
28. Arcangioli MA, Duet A, Meyer G, Dernburg A, Bézille P, et al. (2008) The role of Mycoplasma bovis in bovine respiratory disease outbreaks in veal calf feedlots. Vet $J$ 177: 89-93. [crossref]

29. Duong MC, Alenius S, Huong LTT, Björkman C (2008) Prevalence of Neospora caninum and bovine viral diarrhoea virus in dairy cows in Southern Vietnam. Vet $J$ 175: 390-394. [crossref] 